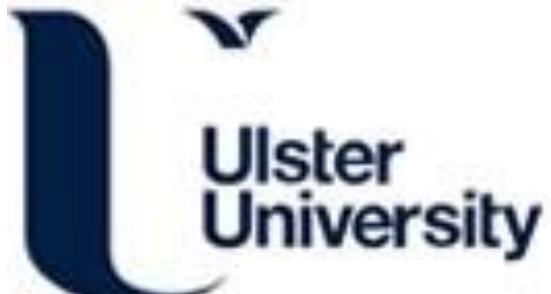

\section{The evolutionary thermal performance and development of a novel thermal diode pre- heat solar water heater under simulated heat flux conditions}

Smyth, M., Quinlan, P., Mondol, J., Zacharopoulos, A., McLarnon, D., \& Pugsley, A. (2017). The evolutionary thermal performance and development of a novel thermal diode pre-heat solar water heater under simulated heat flux conditions. Renewable Energy, 113, 1160-1167. https://doi.org/10.1016/j.renene.2017.06.080

Link to publication record in Ulster University Research Portal

\section{Published in:}

Renewable Energy

Publication Status:

Published (in print/issue): 31/12/2017

DOI:

10.1016/j.renene.2017.06.080

\section{Document Version}

Author Accepted version

\section{General rights}

Copyright for the publications made accessible via Ulster University's Research Portal is retained by the author(s) and / or other copyright owners and it is a condition of accessing these publications that users recognise and abide by the legal requirements associated with these rights.

\section{Take down policy}

The Research Portal is Ulster University's institutional repository that provides access to Ulster's research outputs. Every effort has been made to ensure that content in the Research Portal does not infringe any person's rights, or applicable UK laws. If you discover content in the Research Portal that you believe breaches copyright or violates any law, please contact pure-support@ulster.ac.uk. 


\title{
The evolutionary thermal performance and development of a novel thermal diode pre-heat solar water heater under simulated heat flux conditions
}

\author{
*M Smyth, P. Quinlan, JD Mondol, A. Zacharopoulos, D McLarnon and A Pugsley
}

*Centre for Sustainable Technologies, School of the Built Environment, Ulster University, Newtownabbey BT37 OQB, N. Ireland.

Tel: ++44(0)2890368119, Fax: ++44(0)2890368239, e-mail: m.smyth1@ulster.ac.uk

\begin{abstract}
This paper presents the development through experimental performance characterisation of a pre-heat ICSSWH that utilises a novel thermal diode operation to reduce ambient heat loss during non-collection periods. Using a bespoke thermal flux simulation test facility, 4 prototype versions of the pre-heat thermal diode ICSSWH were produced and evaluated (Mark I to IV) at Ulster University. Each prototype was developed and evolved on the previous design, encompassing performance improvements and fabrication enhancements. The concept has been designed and developed to be a sustainable, pre-heat alternative to other solar water heating systems traditionally used in DHW installations in retro-fit and social housing applications. The highest 6 hour and 3 hour collection efficiency was $33.2 \%$ and $41.97 \%$, respectively under thermally simulated conditions for a unit with capillary matting and 150mbar internal pressure (MIIIb 17). The lowest system ' $\mathrm{U}^{\prime}$ value was $0.98 \mathrm{~W} \mathrm{~m}^{-2} \mathrm{~K}^{-1}$ (long and thin raised pockets, MIV 12) under thermal (solar) flux simulation testing and no draw-off conditions. When the current prototype ICS units are compared with other conventional ICS systems, particularly in terms of thermal retention during non-collection periods, an improved performance is clearly demonstrated. The measured thermal losses were approximately $50 \%$ less than other similarly measured systems.
\end{abstract}

\section{Keywords}

ICSSWH, pre-heat, thermal flux simulation, thermal diode

\subsection{Introduction}

Integrated Collector Storage Solar Water Heaters (ICSSWH) are simple, low cost solar devices. The development of these systems is detailed in Smyth et al [1]. They suffer however significant ambient heat loss, especially at night-time and during non-collection periods [2].

Several studies have been carried out focusing on the improvement of the thermal performance of ICSSWH systems, primarily during night operation. Previous ICSSWH designs have attempted to improve thermal energy storage during non-collection periods by; (i) reducing heat loss from the aperture [3][4][5][6], (ii) reducing convective heat transfer in the collector cavity from the store to the aperture [2] or (iii) reducing heat transfer from the store surface [7][8][9]. Studies to reduce night-time thermal losses include the use of two stores [10]. The use of low pressure and Phase Change Materials (PCM), such as water, within an ICS unit was first suggested by De Beijer [11]. The evaporator is the collector absorbing surface and the condenser is the surface of the inner storage vessel. The working principle exploits the latent heat transfer characteristics of liquid to gas 
phase change whilst reducing heat loss during non-collection periods. The work presented in this paper details the experimental characterisation of a pre-heat ICSSWH that utilises the novel thermal diode operation presented by De Beijer [11].

\subsection{Description of the pre-heat thermal diode ICSSWH}

The conceptual pre-heat thermal diode ICSSWH is constructed from 3 concentric tubes. The outer tube forms the aperture and unit casing. It is made from a transparent material such as glass or Perspex. Its role is to protect the absorbing surface of the next vessel and reduce convective heat loss as well as defining the initial physical appearance of the unit, as shown in Figure 1. The remaining tubes (vessels) combine to create the collector/storage element and are arranged to create an annular space between the concentric walls of these inner and outer vessels.

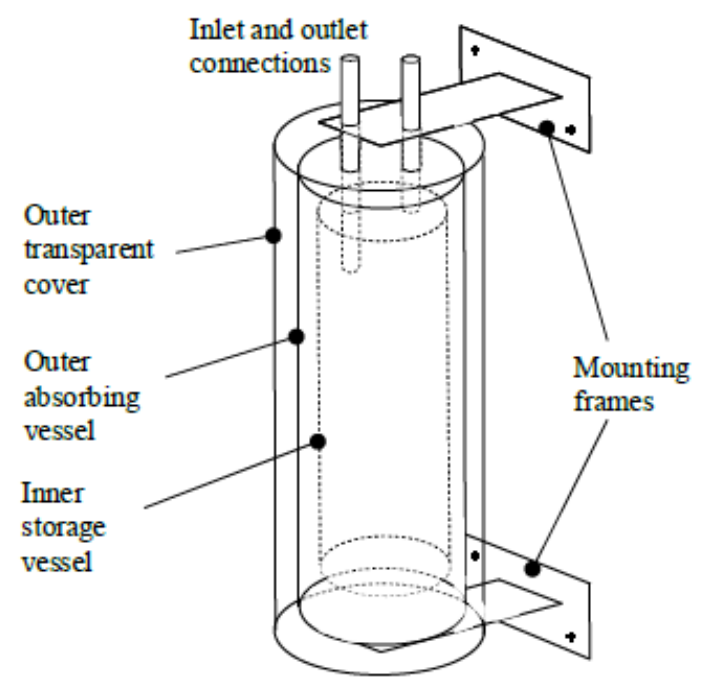

Figure 1: The initial conceptual design of the pre-heat thermal diode ICSSWH

The annular space is partially evacuated to a near vacuum condition and contains a small amount of a liquid/vapour PCM (phase change material). Just like a thermal diode, the design promotes solar collection but reduces thermal losses. During collection periods, solar radiation incident on the outer absorbing surface of annulus chamber (coated with a selective film) causes the PCM in contact with the surface to evaporate at low temperature thus producing a vapour. The PCM vapour condenses on contact with colder inner vessel surface and the collected thermal energy is transferred to water store through latent heat exchange. Condensed PCM runs down the vessel to a reservoir at base of annulus to continue the cycle. During non-collection periods no evaporation takes place due to the partial vacuum in the annulus chamber, thereby reducing heat loss from the store. The generic system operation is illustrated in Figure 2. The annular space can be partially filled with a liquid/vapour phase change material. Water is the most cost effective and environmentally benign PCM, although many other materials may be employed such as alcohols and commercial refrigerants. 


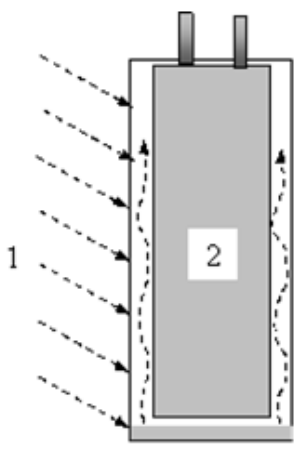

1. Solar ra diation incident on the outer absorbing surface of annulus cham ber

2. Low pressure in the annulus cham ber causes the water to boil at lower tem perature thus producing a vapour

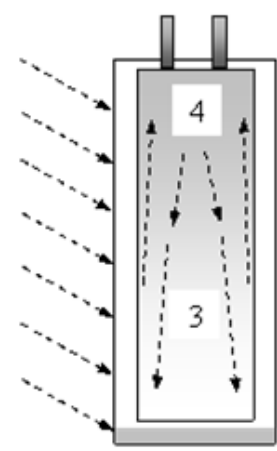

3. The water vapour condenses on contact with colder ICS vessel surface. Collected thermal energy is tranfferred to water store through latent heat ex change. Condensed water runs down vessel to reservoir at ba se of anmulus

4. Heatedwater rises and stratifies within the store lea ding to im proved Solar SavingFractions(SSF)

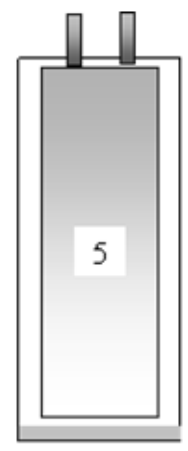

5. During non-collection periods no evaporation takes place and the partial vacuum in the anmulus cham ber reduces heat losses from the store.

Figure 2: Schematic detail of operation principle of the pre-heat thermal diode ICSSWH

A total of 4 prototype versions of the pre-heat thermal diode ICSSWH were produced and evaluated (Mark I to IV). Each prototype developed and evolved on the previous design, encompassing performance improvements and fabrication enhancements as detailed in Table 1 and Figure 3. Where possible the units were fabricated and assembled at Ulster University, with one-off components out-sourced from local fabrication specialists. The units presented for comparison in this particular study comprise of a basic control unit and a series of optimised units using enhanced heat transfer elements.

Table 1: Variants Mark I-IV and enhancements

\begin{tabular}{|l|l|c|c|c|c|}
\hline \multicolumn{1}{|c|}{ Variant } & \multicolumn{1}{|c|}{ Description } & Mass $(\mathrm{kg})$ & $\begin{array}{c}\text { Thermal } \\
\text { mass }(\mathrm{kJ} / \mathrm{K})\end{array}$ & $\begin{array}{c}\text { Outer vessel } \\
\text { surface area } \\
\left(\mathrm{m}^{2}\right)\end{array}$ & $\begin{array}{c}\text { Inner vessel } \\
\text { volume } \\
(\text { litres })\end{array}$ \\
\hline Mark I & $\begin{array}{l}\text { Basic two concentric cylinders } \\
\text { design }\end{array}$ & 23.29 & 10.9 & 1.08 & 28.2 \\
\hline Mark II & $\begin{array}{l}\text { Mark I with sloped pocket and } \\
\text { cowl design }\end{array}$ & 24.03 & 11.3 & 1.08 & 28.2 \\
\hline $\begin{array}{l}\text { Mark } \\
\text { IIIa/b }\end{array}$ & $\begin{array}{l}\text { Mark I/II with non-conducting } \\
\text { connection and top hat divider }\end{array}$ & 25.04 & 12.5 & 1.08 & 28.2 \\
\hline Mark IV & $\begin{array}{l}\text { Mark III with elongated } \\
\text { pocket and cowl design }\end{array}$ & 24.16 & 11.3 & 1.08 & 28.2 \\
\hline
\end{tabular}

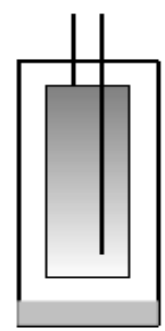

Mark I

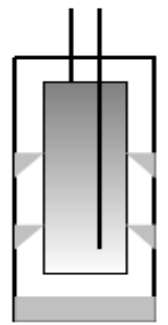

Mark II

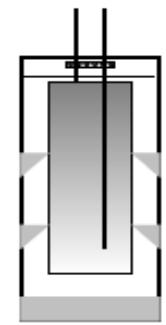

Mark III

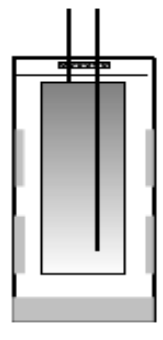

Mark IV

Figure 3: Schematic detail of variants Mark I to IV and enhancements 
The control unit (Mark I) consisted of two vessels, the outer vessel was $300 \mathrm{~mm} \varnothing$ (1m in length) and the inner vessel was $200 \mathrm{~mm} \varnothing(0.9 \mathrm{~m}$ in length). Both vessels were fabricated from $1.5 \mathrm{~mm}$ thick stainless steel sheet. Each vessel had a welded base with a flanging arrangement to allow for access and entry for monitoring instrumentation. The other units were based the same dimensional and construction features used in the fabrication of the control unit, but incorporated a number of design enhancements to aid the heat transfer process during the collection phase and reduce heat loss during non-collection periods.

\subsection{Description of the experimental facility}

The experimental performance of the pre-heat thermal diode ICSSWH units was determined using a thermal flux simulation facility at Ulster University. A total of 59 separate experimental procedures were conducted and included the various versions with performance enhancements such as non-conducting inlet and outlet ports, suppression baffles and mechanisms to increase the wetted heat transfer surfaces through a patented cascade design in the annular cavity. Testing was conducted under thermal flux simulation to have a uniform (constant heat input) basis in order to ascertain performance comparison of the various designs.

The thermal 'solar' simulator comprised of a pair of heater mats positioned unto the outer absorbing surface of the vessel to simulate incident solar flux. T-type copper-constantan thermocouples, which had an error of $\pm 0.5^{\circ} \mathrm{C}$ between 0 and $70^{\circ} \mathrm{C}$, were used to measure the water storage temperatures within the unit versions, various surface temperatures and ambient air temperature. Temperature, pressure and heat input were recorded through a Delta $\mathrm{T}$ logging device linked to a PC, as shown in Figure 4.

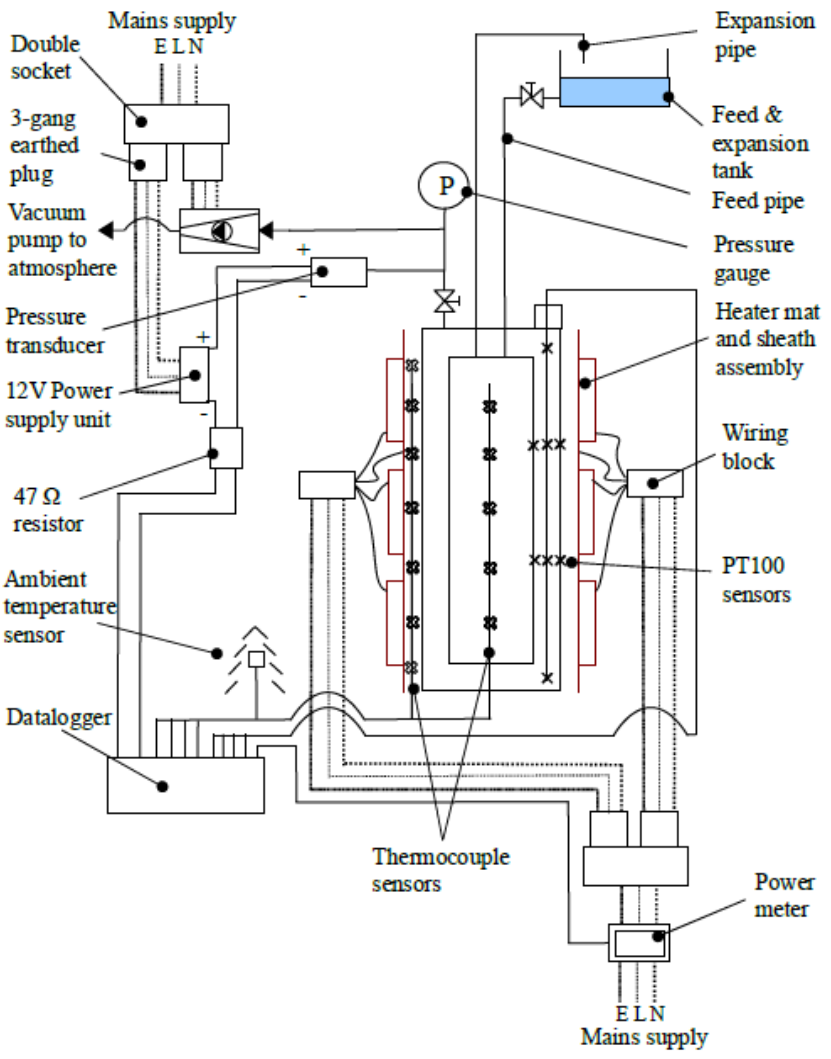




\subsection{Description of the experimental procedure}

Evaluation of collection and thermal retention performance characteristics were performed using thermal simulation and solar simulation conditions. System performance characterisation was based on BS ISO 94595:2007 [12]. No thermal storage draw offs were performed during the tests.

Under thermally simulated heat flux conditions (heater mats and distribution sheath) combined collection and thermal retention experiments were conducted for Marks I to IV. The tests were conducted over 6 to 24 hours in order to determine the daily collection efficiency (6 hours exposure to thermally simulated (constant) conditions) and thermal retention (18 hours cool down). A period of 6 hours collection was chosen since it compares with the average annual daily utilisable insolation period for the London area (Bracknell) with a total monthly mean daily irradiation on a vertical plane of $2.24 \mathrm{kWh} / \mathrm{m}^{2}$ [13]. At the beginning of each experiment period the inner vessel was re-filled and the test started with steady ambient temperatures and uniform tank temperatures.

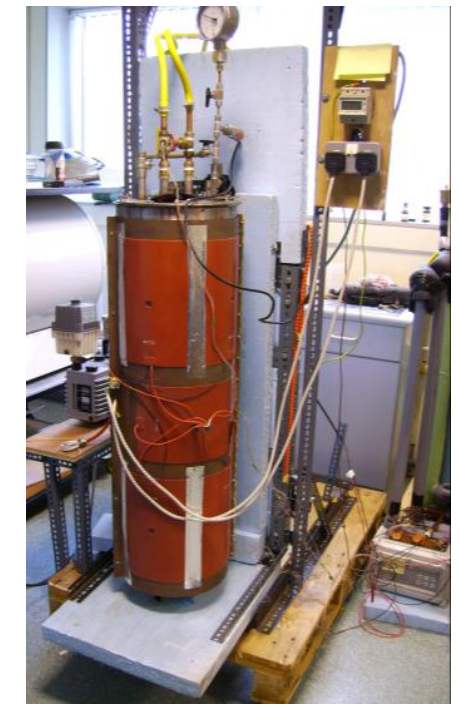

Figure 5: Images of the Mark IV unit under heat flux simulator test conditions

Figure 5 shows the prototype Mark IV rig prior to insulation, ready for testing. The collection period started when the heater mats were turned on and the assembly monitored for six hours after which the heater mats were turned off. The insulation around the unit was removed after the collection period and the cool down period started. After a further 18 hour period the experiment was complete. Test information from the data logger was then downloaded for analysis.

\subsection{Experimental results and analysis}

The experimental performance of each unit was determined from the experimental data retrieved from the extensive testing programme. Thermal store, annulus and external environment were analysed during testing to determine the system characteristics. Thermal store characterisation used the average normalised temperatures and stratification within the store both on collection and cool down to allow analysis of collection and thermal retention efficiencies and develop hypothesis for heat transfer mechanisms into and within the thermal store. Annulus characterisation used the temperature and partial vacuum pressure measurements during collection and 
cool down periods to present the temperature distribution and allow analysis of the sensible and latent heat transfer mechanisms taking place. The external environment is not characterised independently but as part of the characterisations within the thermal store and annulus. Experimentally observed temperatures were used to calculate mean temperatures in the thermal store volume $\left(\mathrm{T}_{\mathrm{av}}\right)$. During collection periods, temperatures recorded within the thermal store at the beginning and end of collection were used to calculate average start temperature $\left(\mathrm{T}_{\text {initial }}\right)$ and average end temperature $\left(\mathrm{T}_{\text {end }}\right)$. Thermal energy collected $\left(\mathrm{Q}_{\mathrm{col}}\right)$ by the unit was determined by

$$
\mathrm{Q}_{\mathrm{col}}=\mathrm{mc}_{\mathrm{p}}\left(\mathrm{T}_{\mathrm{end}}-\mathrm{T}_{\text {initial }}\right)
$$

where $\mathrm{m}$ is the mass of water in the thermal store and $c_{p}$ is the specific heat capacity of the water. The unit collection efficiency was determined by

$$
\eta_{\text {col }}=\left(\frac{\mathrm{Q}_{\text {col }}}{\mathrm{Q}_{\text {supplied }}}\right) \times 100
$$

where $\mathrm{Q}_{\text {supplied }}$ is the energy supplied over the collection period. The collection efficiency varies depending on the collection time period used therefore during evaluation it was measured over a 6 hour period unless otherwise specified. Thermal stratification within the store is characterised by a stratification index $(\sigma)$ calculated using equation (3) below [14]

$$
\sigma=\frac{\left(T_{a v, t}-T_{a v, b}\right)}{\left(T_{a v, t}-T_{a v, b}\right)_{s t a r t}}
$$

where $\mathrm{T}_{\mathrm{av}, \mathrm{t}}$ and $\mathrm{T}_{\mathrm{av}, \mathrm{b}}$ are the average thermal store temperatures within the top 1/5 and bottom 1/5 storage volumes and $\left(\mathrm{T}_{\mathrm{av}, \mathrm{t}}-\mathrm{T}_{\mathrm{av}, \mathrm{b}}\right)_{\text {start }}$ is the temperature difference between the top $1 / 5$ and bottom 1/5 storage volumes at the beginning of the collection period. A de-stratification time constant measured as the time it takes for the stratification index $\sigma$, to decrease to 0.3679 of its initial value, is used to measure de-stratification during the cool down period. Thermal retention efficiency $\left(\eta_{\text {ret }}\right)$ is determined by

$$
\eta_{\text {ret }}=\left(\frac{\mathrm{m} \times \mathrm{c}_{\mathrm{p}}\left(T_{\text {final }}-T_{a m b}\right)}{\mathrm{m \times c} \mathrm{c}_{\mathrm{p}}\left(T_{\text {initial }, c}-T_{\text {amb }}\right)}\right) \times 100
$$

where $T_{\text {initial,c }}$ is the average temperature at the start of the cool-down period, $T_{\text {final }}$ is the average temperature at the end of the cooling period and $\mathrm{T}_{\mathrm{amb}}$ is the average ambient temperature throughout the cool-down period.

The system heat loss coefficient also known as the system 'U' value was calculated from equation (5) [15] 


$$
U_{\text {system }}=\frac{m c_{\text {system }}}{A_{\text {unit }} \Delta t} \ln \left(\frac{\left(T_{\text {initial }, c}-T_{\text {amb }}\right)}{\left(T_{\text {final }}-T_{\text {amb }}\right)}\right)
$$

where $\mathrm{mc}_{\text {system }}$ is the thermal mass of the system based on the mass and specific heat capacity of the individual units and $A_{u n i t}$ is the surface area of the outer vessel.

\subsection{Discussion}

The Mark I unit was the first prototype tested. Four collection and cool-down tests were undertaken. With test MI 1 the control with no PCM at atmospheric pressure (1013mbar) and MI 4 with 3 litres of PCM at 50mbar and with capillary matting. Figure 6 shows the normalised average water temperatures within the thermal store over the collection and cool down for each test. Mark I 1 had a base collection efficiency of $21.57 \%$ whilst the improved (evacuated) Mark I 4 had a collection efficiency of 25.39\%. The 18 hour heat retention efficiencies and system heat transfer coefficients for Mark I tests 1 to 4 and 24 hour heat retention efficiencies and system heat transfer coefficients for Mark I tests 5 (1013 mbar) \& 6 (100 mbar) are shown in Figure 7.

Figure 6: Normalised average thermal store temperatures for Mark 1 tests 1 to 4 for a 6 hour collection period and 18 hour cooling period under thermally simulated test conditions

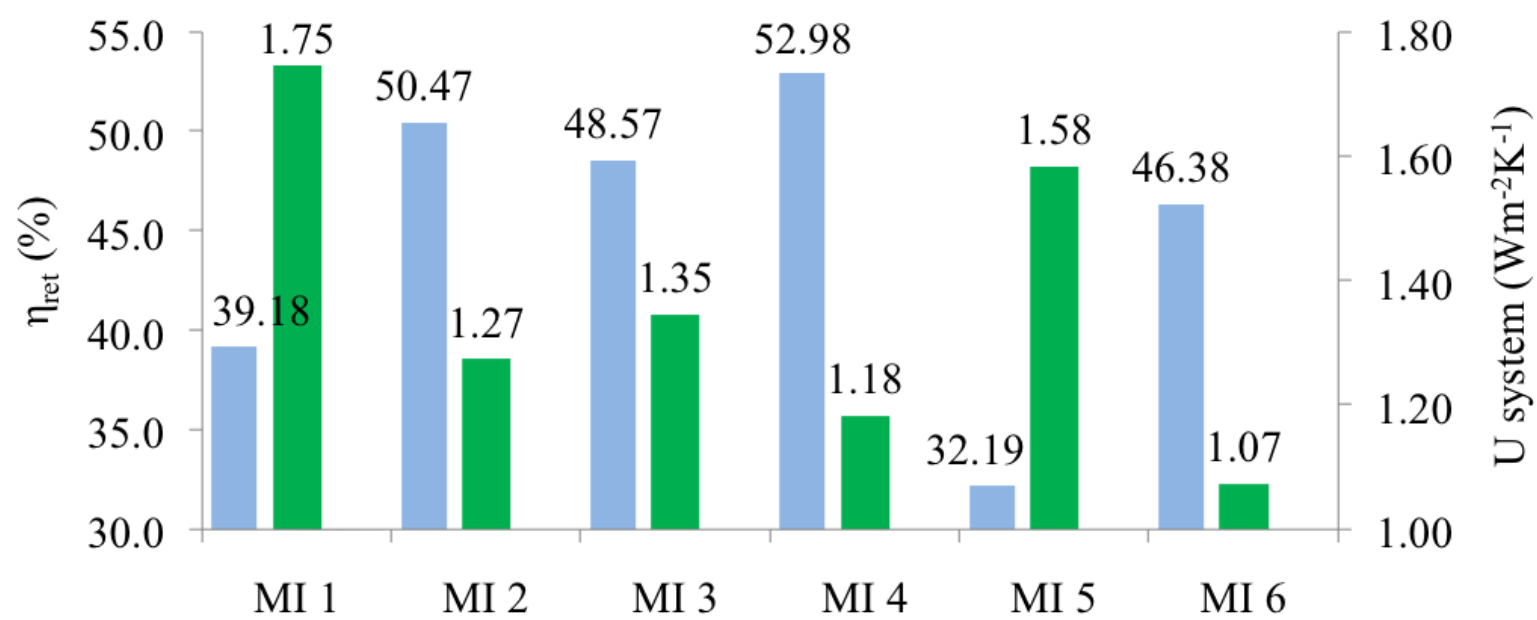

Figure 7: The 18 hour heat transfer coefficient and retention efficiency during Mark I tests 1 to 4 under cool- 
The highest normalised average thermal store temperatures and the highest collection efficiencies were achieved by MI 4. The collection efficiency was significantly improved by introducing the low pressure environment, PCM and capillary matting. This increase occurred because of lower resistance to heat transfer within the annulus. Stratification of water within the thermal store is important in achieving a high solar savings fraction during partial load draw-offs. During collection the greatest stratification occurred during MI 1 whilst MI 4 was more uniform, indicating that most heat was being transferred at a lower level. MI 1 exhibited the lowest heat retention efficiency and highest system 'U' value whilst MI 4 had the highest heat retention efficiency and lowest system 'U' value as illustrated in Figure 7. Compared to MI 1, MI 4 increased heat retention efficiency by $35 \%$ $(52.98 \%)$ and reduced the system ' $\mathrm{U}^{\prime}$ value by $32.5 \%\left(1.18 \mathrm{~W} \mathrm{~m}^{-2} \mathrm{~K}^{-1}\right)$. The results show that the heat retention efficiency and heat transfer coefficient are proportional to the partial vacuum pressure that was maintained over the cool-down period. More details pertaining to the cool-down period are presented by Quinlan [16].

Mark II increased the effective heated surface area in contact with the PCM through the inclusion of raised PCM pockets within the annulus. To prevent the condensate condensing on the inner vessel from flowing back to the bottom of the outer vessel, sloping cowls were paired against the pockets directly opposite on the inner vessel.

The normalised average water temperatures for MII 1 to 3 are shown in Figure 8 and corresponding collection efficiencies improved from $25.81 \%$ (MII 1) to $29.82 \%$ for Mark II 3. The use of the raised pockets and cowl arrangement with capillary matting produced increased collection efficiency, $17.4 \%$ more than MI 4. The average normalised store temperature for MII 3, after 6 hours was $45^{\circ} \mathrm{C}, 21^{\circ} \mathrm{C}$ higher than MI 4. The use of the raised pocket and cowl arrangement also increased stratification (over Mark I) within the thermal store. During the 18 hour cool down period, the MII 3 system 'U' value $\left(1.75 \mathrm{~W} \mathrm{~m}^{-2} \mathrm{~K}^{-1}\right)$ was $32.5 \%$ worse than MI $4\left(1.18 \mathrm{~W} \mathrm{~m}^{-2} \mathrm{~K}^{-1}\right)$ and a reduced retention efficiency of $39.24 \%$ because of the higher pressure due to higher annulus temperatures and water vapour mass increasing conduction and convection losses.

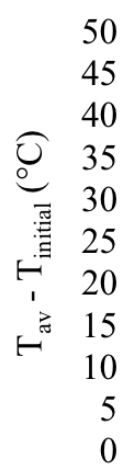

50
45
40
35
30
25
20
15
10
5
0
0
0
0
Figure 8: Normalised average store temperatures for MII test 1 to 3 over a 6 hour collection period under thermally simulated test conditions

Mark IIIb (variants IIIa represented similar designs tested to determine heat loss only and did not use the solar simulated flux experimental procedures) was similar to Mark II except with a thermal break and combined inlet and outlet port, designed to reduce heat loss by direct metal to metal conduction from the inner thermal store to 
the outer vessel lid surface. The design also included a 'Top Hat' disc that isolated vapour from condensing on the upper external surface lid.

Selected test collection efficiencies, normalised average store temperatures, store thermocline development and annulus temperature and pressures for Mark IIIa are used to demonstrate performance (Figures 9 and 10).

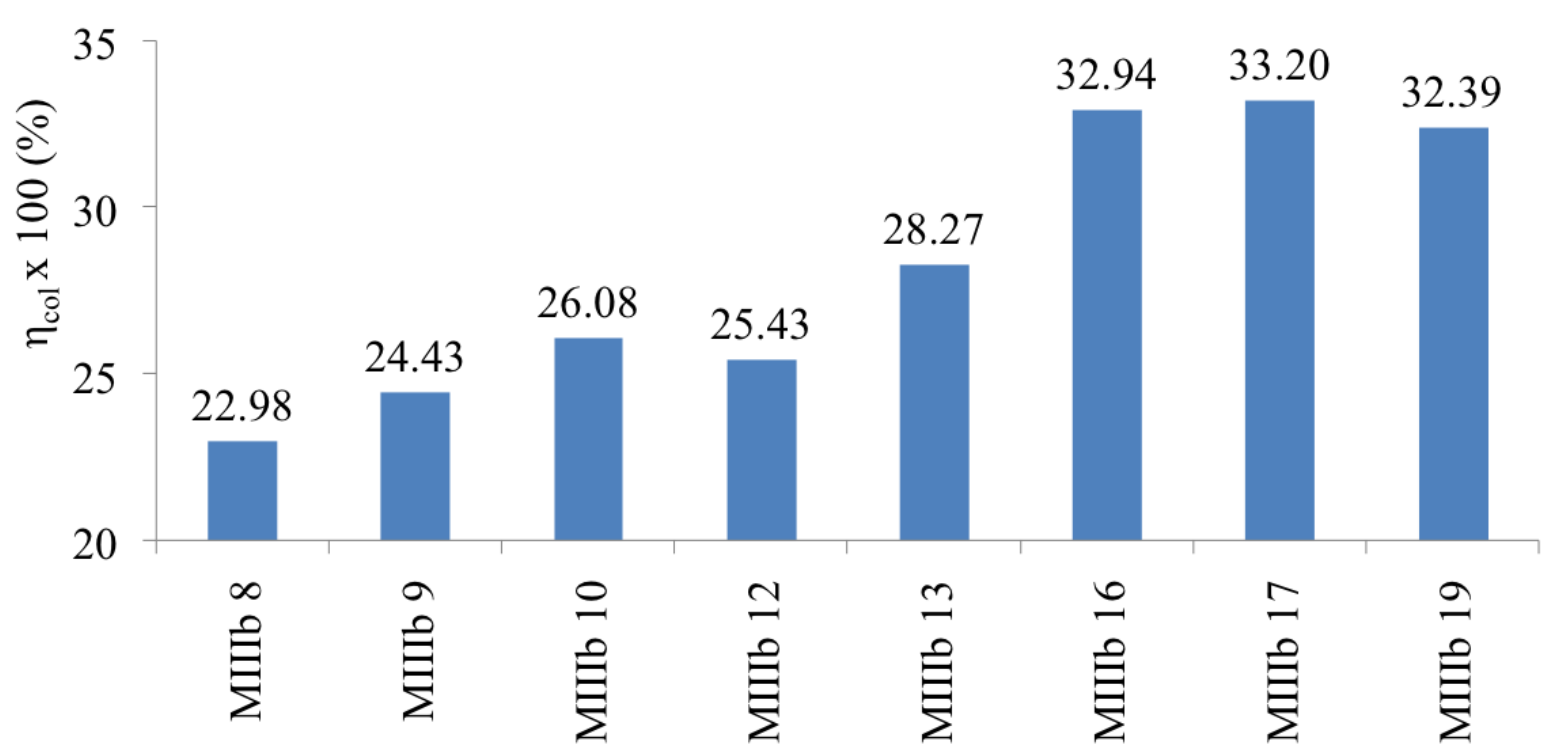

Figure 9: Collection efficiencies for Mark IIIb selected tests under thermally simulated test conditions
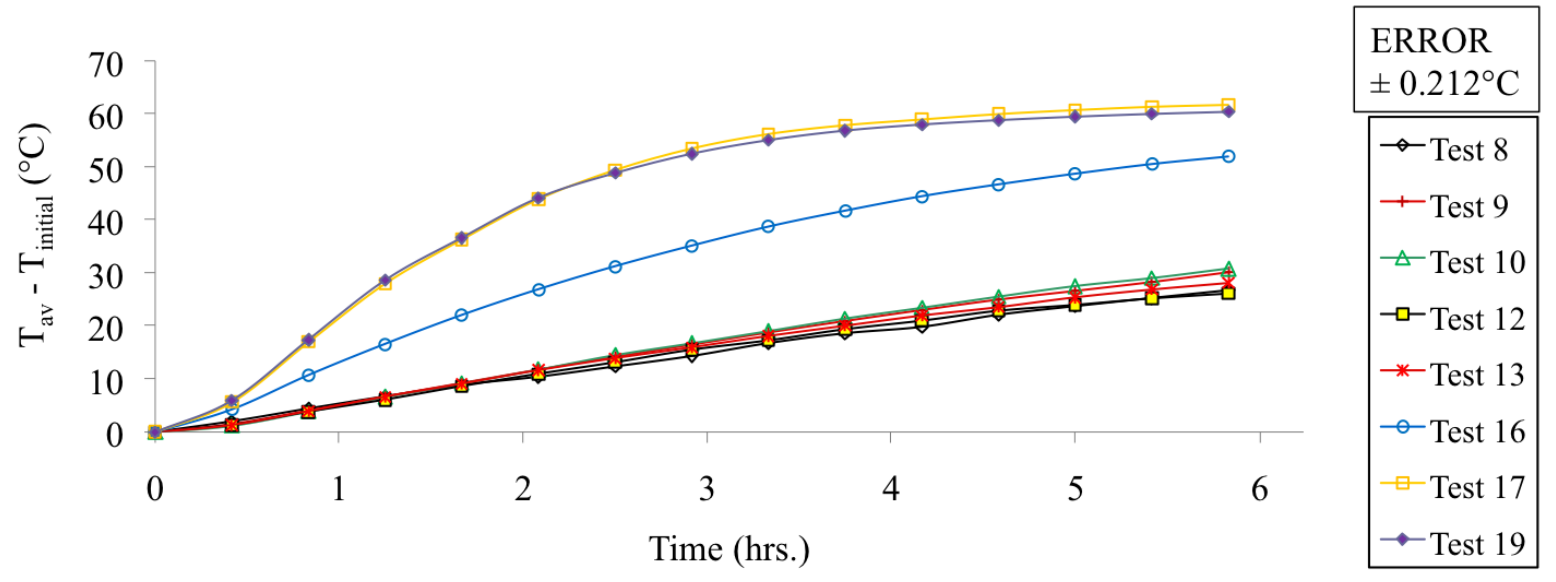

Figure 10: Average normalised vessel store temperatures for Mark IIIb selected tests over a 6 hour collection period under thermally simulated test conditions

Tests MIIIb 17 and 19, which used both capillary matting and a partial vacuum pressure of 150mbar, achieved the highest normalised average temperatures with rapid heat up and maintained higher temperatures. The 6 hour collection efficiencies were $33.2 \%$ and $32.39 \%$, respectively as shown in Figure 9 (their 3 hour collection efficiencies were was $41.97 \%$ and $40.92 \%$, respectively). Figure 10 shows how the average normalised thermal store temperature for MIIIb 17 and 19 increases more quickly during the first 3 hours than during the remaining collection period indicating that a heat saturation point is reached. This was evidenced in thermocline development where there is rapid stratification during the first three hours after which there is heat saturation in 
the upper portion of the thermal store. By the 4th hour a steady state position is reached in the upper part of the vessel. At higher pressures, the annulus contains a greater mass of air, which when heated causes greater convective flow and thus better initial transfer from the outer surface to the inner store.

The benefit of the thermal break is shown by the increase in the collection efficiency from $29.82 \%$ in MII 3 to $32.94 \%$ and $33.2 \%$ for tests 16 and 17 , respectively. The benefit of the capillary matting is demonstrated by a 29.5\% increase in collection efficiency of MIIIb 16 over MIIIb 12 (Top Hat). The effect of the Top Hat on performance can be seen by comparing the annulus sensors and thermoclines. The Top Hat may have the effect of pushing the heat further down the annulus.

Evidence that water within the raised pockets is evaporating and then refilling with condensate is shown by the PT100 4 temperatures, circled in Figure 11. PT100 4 is positioned so as to measure the temperature of liquid PCM $5 \mathrm{~mm}$ from the top of the raised pocket. When enough PCM evaporates without the pocket being refilled the sensor will measure the space temperature (just above the pocket liquid level) in the annulus which will be at a higher temperature than the condensate. But when the pocket refills again with condensate the temperature measured will fall back again.
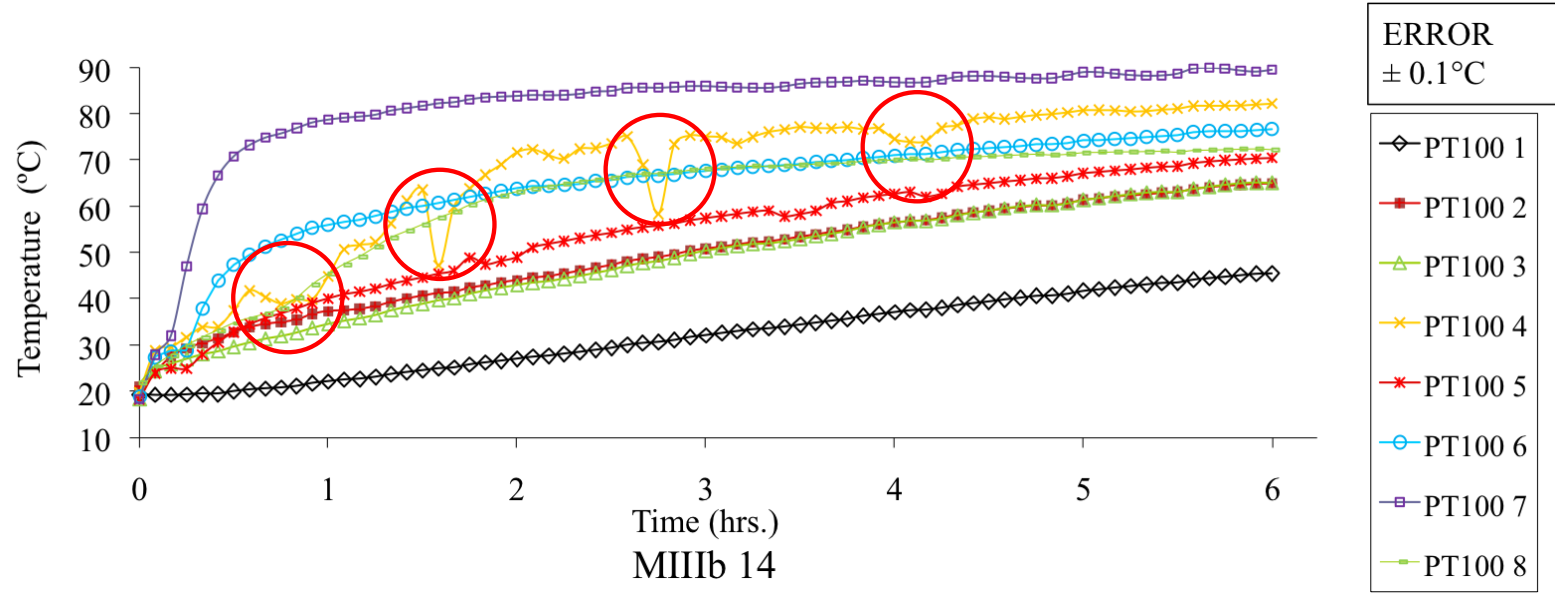

Figure 11: Annulus temperatures every for MIIIb 14 over a 6 hour collection period under thermally simulated test conditions

Mark IV was designed to increase collection efficiency by increasing the amount of PCM in the annulus that was in direct contact with the heat absorbing surface through making the raised pockets longer and thinner. Additionally, the cowl was modified to permit upward flow of vapour but prevent downward flow of condensate (beyond the designated pocket). The results of these design modifications for collection and cool down under thermally simulated test conditions are presented. Selected tests from the test programme are shown to reduce duplication and allow specific design characterisation and performance to be demonstrated more clearly. 


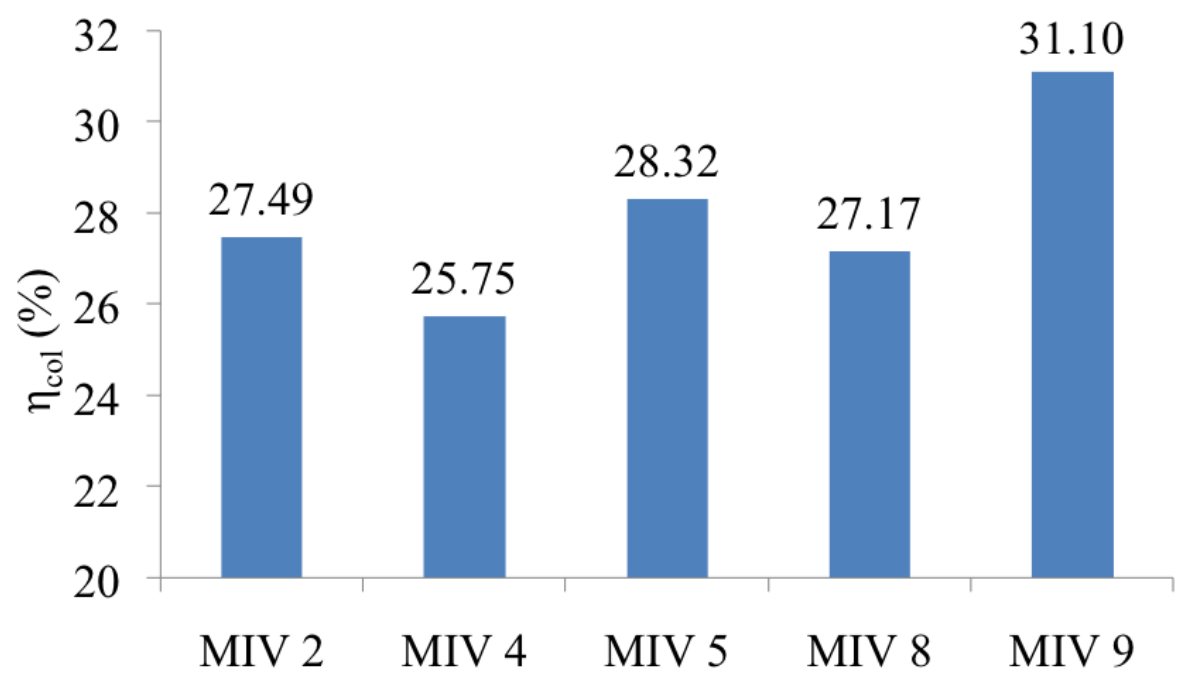

Figure 12: The 6 hour collection efficiencies for Mark IV selected tests under thermally simulated test conditions

The highest collection efficiency as shown in Figure 12 was MIV 9 at 31.1\% which was 6\% lower than the highest 6 hour collection demonstrated by MIIIb 17. The annulus temperature measurements indicate the presence of a strengthening convective cell in the upper region which reduces the temperature differences in the region as temperature increases. In MIV 5, holes in the cowls allowed a convective cell to be established across more than one region, this reduced temperatures in the upper region whilst increasing the temperature in the middle region. Comparing thermoclines (Figure 13), MIV 9 exhibits a large temperature stratification difference from previous tests, especially after 2 hours, where MIIIb 19 maintained stratification throughout the thermal store indicating strong heat transfer to the top of the thermal store. MIV 9 however has no stratification after three hours in the top $80 \%$ of the thermal store suggesting uniform heating of this region. This is supported by analysis inner PT100 sensors situated 500mm from the top of the annulus (half way down) having the same temperature as PT100 sensors at the top of the annulus.

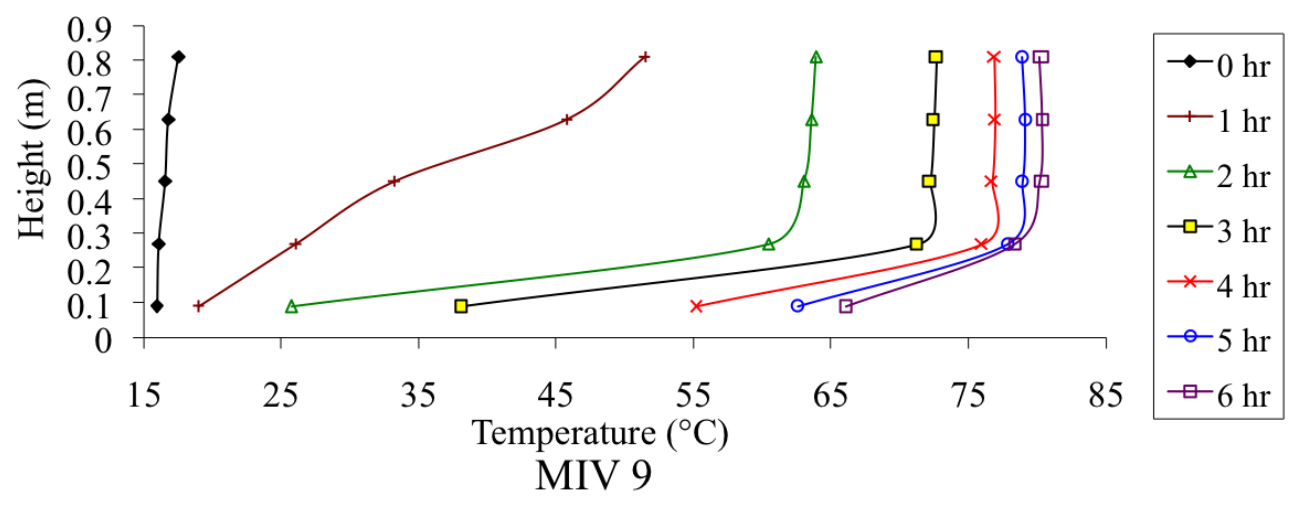

Figure 13: Hourly thermoclines during the collection period of Mark IV 9 under thermally simulated test conditions, (error $\left.\pm 0.15^{\circ} \mathrm{C}\right)$ 
The lowest system 'U' value (Figure 14) for Mark IV (MIV 1) was $1.27 \mathrm{~W} \mathrm{~m}^{-2} \mathrm{~K}^{-1}$ at 50mbar 7.6\% higher than MI 4. The corresponding retention efficiency for MIV 1 was 56.9\%. At 150mbar (MIV 3) the system 'U' value increased $15.2 \%$ to $1.46 \mathrm{~W} \mathrm{~m}^{-2} \mathrm{~K}^{-1}, 8.1 \%$ more than the system ' $\mathrm{U}$ ' value of MI 3 at $100 \mathrm{mbar}$. The reason why Mark IV tests have higher heat losses than Mark I is due to higher average thermal store temperatures. The annulus of MIV units will therefore be warmer and therefore contain more water vapour by mass which will speed up heat loss by convection and conduction. Higher temperatures will also lead to increased radiative heat loss. Comparing tests MIV 1 and 8, the use of capillary matting did not affect the system 'U' value significantly.

60
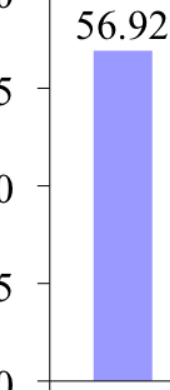

\subsection{6}
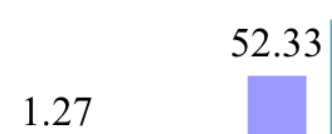

0

Figure 14: Heat transfer coefficient and retention efficiencies for Mark IV tests under thermally simulated test conditions

Table 2: Summary of prototype performances using various parameters

\begin{tabular}{|c|c|c|c|c|c|c|c|}
\hline Mark & $\begin{array}{c}\text { Test } \\
\text { conditions }\end{array}$ & Test type & $\begin{array}{c}\text { Best } 6 \\
\text { hour } \\
\text { collection } \\
\text { efficiency } \\
(\%)\end{array}$ & $\begin{array}{c}\text { Best } 6 \\
\text { hour temp } \\
\text { rise }\left({ }^{\circ} \mathrm{C}\right)\end{array}$ & $\begin{array}{l}\text { Highest } \\
\text { temp } \\
\text { achieved } \\
\left({ }^{\circ} \mathrm{C}\right)\end{array}$ & $\begin{array}{c}\text { Best } \\
\text { system } \\
\text { 'U' value } \\
\left(\begin{array}{c}\mathbf{W m}^{-2} \mathbf{K}^{\prime} \\
\left.{ }^{1}\right)\end{array}\right.\end{array}$ & $\begin{array}{c}\text { Best } \\
\text { retention } \\
\text { efficiency } \\
(\%)\end{array}$ \\
\hline I & $\begin{array}{l}\text { Thermal } \\
\text { simulation }\end{array}$ & $\begin{array}{l}\text { Collection/ } \\
\text { cooldown }\end{array}$ & $\begin{array}{l}25.39 \\
\text { (MI 4) }\end{array}$ & $\begin{array}{l}23.9^{\circ} \mathrm{C} \\
\text { (MI 4) }\end{array}$ & $\begin{array}{l}42.6^{\circ} \mathrm{C} \\
\text { (MI 1) }\end{array}$ & $\begin{array}{l}1.18 \\
\text { (MI 4) }\end{array}$ & $\begin{array}{l}52.98 \\
\text { (MI 4) }\end{array}$ \\
\hline I & $\begin{array}{l}\text { Indoor } \\
\text { Ambient }\end{array}$ & $\begin{array}{l}\text { Thermal } \\
\text { retention }\end{array}$ & & & & $\begin{array}{l}1.07 \\
\text { (MI 6) }\end{array}$ & $\begin{array}{l}46.38 \\
\text { (MI 6) }\end{array}$ \\
\hline II & $\begin{array}{l}\text { Thermal } \\
\text { simulation }\end{array}$ & $\begin{array}{l}\text { Collection/ } \\
\text { cooldown }\end{array}$ & $\begin{array}{l}29.82 \\
\text { (MII 3) }\end{array}$ & $\begin{array}{l}47^{\circ} \mathrm{C} \\
\text { (MII 3) }\end{array}$ & $\begin{array}{l}65.7^{\circ} \mathrm{C} \\
\text { (MII 3) }\end{array}$ & $\begin{array}{l}1.75 \\
\text { (MII 3) }\end{array}$ & $\begin{array}{l}39.24 \\
\text { (MII 3) }\end{array}$ \\
\hline IIIa & $\begin{array}{l}\text { Thermal } \\
\text { simulation }\end{array}$ & Collection & \begin{tabular}{|l|}
21.63 \\
(MIIIa 11)
\end{tabular} & $\begin{array}{l}19^{\circ} \mathrm{C} \\
\text { (MIII 17) }\end{array}$ & $\begin{array}{l}34^{\circ} \mathrm{C} \\
\text { (MIIIIa 16) }\end{array}$ & & \\
\hline IIIa & $\begin{array}{l}\text { Indoor } \\
\text { Ambient }\end{array}$ & $\begin{array}{l}\text { Thermal } \\
\text { retention }\end{array}$ & & & & $\begin{array}{l}0.86 \\
\text { (MIIIa 2) }\end{array}$ & $\begin{array}{l}54.18 \\
\text { (MIIIa 2) }\end{array}$ \\
\hline IIIb & $\begin{array}{l}\text { Thermal } \\
\text { simulation }\end{array}$ & Collection & $\begin{array}{l}33.20 \\
\text { (MIIIb 17) }\end{array}$ & $\begin{array}{l}62^{\circ} \mathrm{C} \\
(\mathrm{MIIb} \text { 17) }\end{array}$ & $\begin{array}{l}78^{\circ} \mathrm{C} \\
(\mathrm{MIII} \text { 17) }\end{array}$ & & \\
\hline IV & $\begin{array}{l}\text { Thermal } \\
\text { simulation }\end{array}$ & $\begin{array}{l}\text { Collection/ } \\
\text { cooldown }\end{array}$ & $\begin{array}{l}31.10 \\
\text { (MIV 9) }\end{array}$ & $\begin{array}{l}60^{\circ} \mathrm{C} \\
\text { (MIV 9) }\end{array}$ & $\begin{array}{l}77^{\circ} \mathrm{C} \\
\text { (MIV 9) }\end{array}$ & $\begin{array}{l}1.27 \\
\text { (MIV 1) }\end{array}$ & $\begin{array}{l}56.92 \\
\text { (MIV 1) }\end{array}$ \\
\hline IV & $\begin{array}{l}\text { Solar } \\
\text { simulation }\end{array}$ & $\begin{array}{l}\text { Collection/ } \\
\text { cooldown }\end{array}$ & $\begin{array}{l}36.17 \\
\text { (MIV 12) }\end{array}$ & $\begin{array}{l}15.7^{\circ} \mathrm{C} \\
(\mathrm{MIV} 12)\end{array}$ & $\begin{array}{l}35^{\circ} \mathrm{C} \\
\text { (MIV 12) }\end{array}$ & $\begin{array}{l}0.98 \\
\text { (MIV 12) }\end{array}$ & $\begin{array}{l}60.65 \\
\text { (MIV 1) }\end{array}$ \\
\hline
\end{tabular}

The optimal performance of each prototype (and selected tests) in terms of collection and retention efficiency, highest temperature achieved and lowest system "U" value is summarised in Table 2. The highest collection efficiency was $36.17 \%$ by MIV under simulation conditions. The lowest system ' $U$ ' value when PCM was in the annulus was $0.86 \mathrm{~W} \mathrm{~m}^{-2} \mathrm{~K}^{-1}$ by MIIIa (heat loss only test and not described in this study)) and $0.98 \mathrm{~W} \mathrm{~m}^{-2} \mathrm{~K}^{-1}$ 
(MIV 12) under thermally simulated conditions when the unit annulus pressure was 50mbar in both cases. The highest average temperature was $78^{\circ} \mathrm{C}$ achieved by MIIIb 17. The work presented in this study represents progenitor material that has led to significant new work based on the thermal diode principle. Pugsley et al [17] presents a more detailed theoretical analysis of the thermal diode in a Hybrid PVT collector.

\subsection{Conclusions}

A novel thermal diode pre-heat solar water heating system has been designed and developed to be a sustainable, alternative to pre-heat solar water heating systems traditionally used in DHW installations. The concept was based on the operating principles of evacuation and PCMs to offer a cost effective alternative for retro-fit and social housing applications. A number of prototypes were designed, fabricated, tested and evaluated using a bespoke thermal simulation heat flux test facility. The highest 6 hour collection efficiency was 33.2\% and the highest 3 hour collection efficiency was $41.97 \%$ under thermally simulated conditions for MIIIb 17 . The lowest system 'U' value was $0.98 \mathrm{~W} \mathrm{~m}^{-2} \mathrm{~K}^{-1}$ (MIV 12) under thermal flux testing and no draw-off conditions (or $0.86 \mathrm{~W}$ $\mathrm{m}^{-2} \mathrm{~K}^{-1}$ (MIV 12) under heat loss only testing). When the current prototype ICS units are compared with other conventional ICS systems, particularly in terms of thermal retention during non-collection periods, an improved performance is clearly demonstrated [18]. The measured thermal losses were approximately 50\% less than other similarly measured systems.

The study concludes that the system performance is optimal with between 3 to 5 litres of PCM in the annulus at a low partial vacuum pressure (enough to wet the heated surface areas but not so as to contribute significantly to the thermal mass). Other significant enhancements that were shown to improve performance were a high surface area to PCM mass ratio through the use of raised pockets, elongated pockets and capillary matting, use of a transparent cover and heat loss reduction methods such as a vessel thermal break feature for the inlet and outlet ports. Thermal retention was improved through lower partial vacuum pressures and by using the thermal break/combined inlet and outlet and pipe connections made from the vessel base, using stainless steel vessels, a transparent cover and from an increased thermal mass. Thermal store stratification improved through vertical orientation, the use of the Top Hat feature, raised pockets and annulus compartmentalisation, use of a stainless steel inner vessel, thermal break, back insulation and addition of a transparent cover. A system designed upon features exhibited in variants MIIIb 17 and MIV 12 has been shown to be the optimal configuration.

Through experimental and parametric evaluation, a unique pre-heat ICS solar water heating system has been designed, developed, analysed and presented. Significant steps have been made towards a potential commercial future, but in order to fully realise this goal, much more study is required.

Acknowledgements and Funding: This work was supported through funding from Invest Northern Ireland, Proof of Concept scheme.

\section{NOMENCLATURE}
$\mathbf{A}_{\text {unit }} \quad$ surface area of unit $\left(\mathrm{m}^{2}\right)$
$\mathbf{c}_{\mathbf{p}} \quad$ specific heat capacity of water $(\mathrm{J} / \mathrm{kgK})$
m mass of water $(\mathrm{kg})$ 
$\mathbf{m c}_{\text {system }}$ thermal capacity $(\mathrm{J} / \mathrm{K})$

$\mathbf{Q}_{\text {col }}$ thermal energy collected (J)

$\mathbf{Q}_{\text {supplied }}$ thermal energy supplied (J)

$\mathbf{U}_{\text {system }}$ system heat loss coefficient $\left(\mathrm{W} \mathrm{m}^{-2} \mathrm{~K}^{-1}\right)$

$\Delta \mathbf{t} \quad$ time (secs)

efficiency

diameter

\section{Subscripts}

416

amb average ambient temperature

av,b average water temperature at bottom $1 / 5$ of vessel

$\mathbf{a v , t}$ average water temperature at top $1 / 5$ of vessel

end average water temperature at end of heating period

final average final water temperature at end of cooling period

initial average initial water temperature

initial,c average initial water temperature at start of cooling period

ret heat loss retention

\section{REFERENCES}

[1] Smyth M, Eames PC and Norton B, 2006. Integrated Collector Storage Solar Water Heaters. Renewable and Sustainable Energy Review, Vol. 10, Iss.6, pp 503-538

[2] Tripanagnostopoulos Y \& Yianoulis P, 1992. Integrated collector/storage systems with suppressed thermal losses. Solar Energy, Vol. 48, No. 1, pp 31 - 43 [3] Baer S, 1975. Breadbox Water Heater Plans. Zomeworks Corporation, P.O. Box 25805, N.M. 87125, U.S.A.

[4] Bishop RC, 1983. Superinsulated Batch Heaters for Freezing Climates. Proc. of the 8th National Passive Solar Conference, Sante Fe, New Mexico, U.S.A., Sept. 7-9, pp 807-810 [5] Schmidt C, Goetzberger A \& Schmid J, 1988. Test Results and Evaluation of Integrated Collector Storage Systems with Transparent Insulation. Solar Energy, Vol. 41, No. 5, pp 487-494

[6] Schmidt C \& Goetzberger A, 1990. Single-Tube Integrated Collector Storage Systems with Transparent Insulation and Involute Reflector. Solar Energy, Vol. 45, No. 2, pp 93-100 [7] Stickney BL \& Nagy C, 1980. Performance Comparisons of Several Passive Solar Water Heaters. Proc. of the 5th National Passive Solar Conference, Amherst, Massachusetts, U.S.A., pp 1071-1075, Oct. 16-26 [8] Burton JW \& Zweig PR, 1981. Side by Side Comparison Study of Integral Passive Solar Water Heaters. 
[9] Bainbridge DA, 1981. The Integral Passive Solar Water Heater Book. The Passive Solar Institute, PO Box 722, Davis, CA 95616, U.S.A [10] Tripanagnostopoulos Y \& Souliotis MK, 2003. Double tank ICS solar systems. ISES Solar World Congress, 448 Goteborg, Sweden

449 [11] De Beijer, H.A. "Product Development in Solar Water Heating", Proc. of the $5^{\text {th }}$ World Renewable Energy 450 Congress, Florence, Italy, pp 201-204, September 1998

451 [12] Anon. 2007a. Solar Heating - Domestic Water Heating Systems- Part 5: System Performance characterization by means of whole-system tests and computer simulation. BS ISO 9459-5:2007, British Standards Institution, London, UK [13] Anon. 2007b. Chartered Institute of Building Services Engineers Environmental Guide A. 7th Edition, Merton, UK [14] Gnafakis C \& Manno VP, 1989. Transient destratification in a rectangular enclosure. Transactions of the American Society of Mechanical Engineers, Vol. 111, pp 92 -99

[15] Visser H \& Van Dijk HAL, 1991. Test procedures for short term thermal stores. Kluwer Academic Publishers, Dordrecht, The Netherlands [16] Quinlan P, 2010. The Development of a Novel Integrated Collector Storage Solar Water Heater (ICSSWH) Using Phase Change Materials and Partial Evacuation. PhD Thesis, University of Ulster [17] Pugsley A, Smyth M, Mondol JB, Zacharopoulos A \& Mattia L, 2016. Experimental characterisation of a flat panel integrated-collector-storage solar water heater featuring a photovoltaic absorber and a planar liquidvapour thermal diode. 11th ISES EuroSun Conference, October 2016, Majorca, Spain [18] Singh R, Lazarus IJ \& Souliotis M, 2016. Recent developments in integrated collector storage (ICS) solar water heaters: A review. Renewable and Sustainable Energy Reviews. Vol. 54, pp 270-298 